\title{
A Validity and Reliability Study of the SocioVirtualization Perception Scale (SVPS)
}

\author{
Özgen KORKMAZ* \\ Department of Computer Education and Instructional Technology, Mevlana University \\ Education Faculty, Turkey \\ Ertuğrul USTA \\ Department of Computer Education and Instructional Technology, Mevlana University \\ Education Faculty, Turkey \\ İbrahim KURT \\ Department of Educational Science, Mevlana University Education Faculty, Turkey
}

\begin{tabular}{ll}
\hline \hline Article history & Individuals are socialized by embracing material and spiritual cultural \\
Received: & characteristics that a society possesses. This process is put into practice \\
01.05 .2014 & with socialization factors such as family, peers, school and media. \\
Received in revised form: & Interaction and communication in social life have started to carry \\
14.05 .2014 & socialization factors to different levels with contribution by virtual \\
& environments in our day. Since determination of the level of interaction \\
Accepted: & and relationships shifting from real life to virtual life is not yet a \\
14.05 .2014 & sufficiently discussed issue in the body of literature, we could not come \\
& across an instrument of measurement, whose reliability and validity have \\
Key words: & been proved, for measuring levels of what sort of transformations, \\
\hline Socialization, Socio- & advancements and developments have been experienced in terms of \\
virtualization, Scale & socialization factors after society's beginning of turning to virtual \\
development & environments. In this respect, the research objective is to develop a scale \\
& for determining levels for relationships of individuals in social life \\
& shifting to virtual environments. 294 individuals constitute the research \\
& study group. Exploratory and confirmatory factor analysis, item-factor \\
& total correlation, adjusted correlation and distinguishing features of items \\
& were calculated for investigating validity of the scale. Internal \\
& consistency coefficient and stability levels of the scale were calculated \\
for investigating reliability of the scale. As a result, the SVPS is a 5-point & Likert scale that can be grouped under three factors and consists 30 items. \\
& Analyses put forward that this scale is a reliable and valid instrument for \\
measuring levels of socio-virtualization perception of a society's & individuals in virtual environments. \\
\hline \hline
\end{tabular}

* Correspondence: Özgen KORKMAZ,ozgenkorkmaz@gmail.com 


\section{Introduction}

Throughout history, societies have transferred their accumulations to individuals and newly growing generations and ensured sustaining existence of their societies through their socialization. The concept of socialization, which was defined by sociologists from different aspects, is described as preparing individuals, who have participated in society, for social life and the process of their integration into society and their adaptation to their environments (Dönmezer,1984; Doğan, 2012). While on the one hand individuals embrace the things possessed by society, on the other hand they are raised as personalities. In this regard, socialization is internalization of objective, social reality and its relative interpretation according to individuals (Jarvis, 1983). A socialized individual experiences a process of learning itself and his/her environment by embracing values and norms owned by society and fulfilling social roles (Marshall 1999). Humans experience the process of becoming a being that they are supposed to be by living within a society as different from other organisms (Evkuran 2010). The fact that humans are social beings has entailed them to be definitely present in a society. Humans, who are living in social life, have to live by considering the things that society has and commonly shared social values (Doğan, 1993). The process of transferring what society has to individuals has socialized them. While making each of its members embrace understanding of the social 'us', each individual also experiences a process of melting themselves as a 'self' within society (Celkan,1991). Thus, while individuals were learning what is social, they have also begun to set their behaviors and lives according to their societies. Primary ways of conduct are learned by individuals with socialization and they go on with their lives in the framework of various ideals while gaining social values (Ozankaya 1986).

Individuals experience a process where they learn values, customs, traditions, knowledge and skills in an interactive way. Socialization is considered as a process of interaction between individuals and society rather than something where individuals are constantly influenced by society (Zeichner \& Tabachnick, 1985). Individuals experience this in every part of life and throughout their lives; also through teaching this to newly growing generations, values and norms of society are transferred to new generations and societies are constantly kept alive in terms of socialization. In fact, each individual goes on with their lives in society as a product of their own culture. While on the one hand humans as social beings develop biologically, on the other hand their personality arises with values and norms of society within the process of socialization. After a process of solidarity and cooperation for humanity along with other people in societies, humans who were different from each other began to live together (Güvenç, 1995).

It is possible to mention various instruments of socialization for giving the things in a society to individuals. Among them, family, games and peers, education, environment, clubs, associations, artistic activities and mass communication devices are at the forefront (Josept, 1994; Özgüven, 1996). Individuals begin to embrace how they are supposed to live in society with family, peers, school and media (Coser, 1987, Parke at al., 2008). Individuals, whose process of participating in society starts with their family who brought them to this world, try to perceive and understand what is going on in their surroundings. Interactive process of socialization starts to manifest itself more after what individuals share with their peers increase and they begin to spend more time with their peers. Since the things that will be formally gathered throughout education are obvious, literary, geographical and physical things that belong to society and history as well as their situation of socialization begin to be given to individuals as things that will be necessary for them in society throughout their life. Socialization forms social identities of individuals while they are living in society. It was 
stated as a result of researches conducted that innate nature of humans, culture and education have an influential role on emergence of social identity (Plummer 2010; Aluja \& Blanch, 2004).

\section{Society and Virtual Environment}

It is observed in the context of literature and conducted researches that tools of socialization have fulfilled the same function in historical process in general sense ( Coser, 1987, Parke at al., 2008; Jarvis, 1983; Zeichner \& Tabachnick, 1985; Dönmezer,1984; Doğan, 2012; Josept, 1994; Özgüven, 1996). Albeit tools of socialization have tried to fulfill the same functions until now, as lately various transformations and developments are the case in terms of these tools, it can be argued that socialization have been influenced by this situation. For instance, individuals access many news, events and information more quickly or can be quickly influenced by them.

It can be said that knowledge and technology, which are advancing and developing in our time, making their presence felt in every aspect has brought individuals' relationship with tools of socialization to a little bit more different levels compared to previous years. Individuals, who live in an information and technology society, have started to life socialization process different than their fathers and grandfathers. The time which is spent by humans in social life has started to decrease more in our age compared to previous years. Also, interaction between humans and machines even further increases with proliferation of technological devices and individuals begin to spend more time with televisions, mobile phones, computers and internet starting from early ages. This process results in various changes and differentiations with regard to tools of socialization. It can be said that a different process compared to previous eras has begun to be experienced ranging from domestic interaction and communication, games played with peers and chats initiated with peers to technological devices used in the area of education and to the fact that media is now everywhere along with technology. While contributions of these developments on socialization last, it is also observed that individuals now use mass communication devices more for their relationship with their environment, for interactions of social life and receiving values and norms possessed by society with beginning to use technological things. As a result, it can be said that these phenomena has begun to be slowly observed in attitudes and behaviors. It is important to re-think and analyze instruments that are effective in socialization process with technological advancements that have started to make themselves felt (Erturgut, 2008). Worldwide use of internet and individuals spending their time in virtual environment increasingly continue day by day. In this process, it was estimated that about $71 \%$ of population in developed countries and about $21 \%$ of population in developing countries will spend their time in virtual environment (IMEF, 2011). As a result of an increase in this ratio, it can be argued that new situations related to social life and socialization, which are determinative of living spheres of individuals, will be the case. Considering that particularly the young generation, who has recently participated in society (between the ages of 16 and 24), has the highest ratio of using virtual environment (TÜIK, 2011), it can be anticipated that various social phenomena might emerge among these individuals and previous generation.

However, virtual environment manifests itself with many positive aspects for learning new cultures, establishing and developing dialogues thanks to opportunities it presents to people and for presenting a world that is possible for putting new social movements as well as social and political discourses in circulation (Binark \& Bayraktutan, 2008). Opportunities of 
internet and social networking sites such as YouTube, dailymotion, Facebook, geocities and twitter do not only contain a one-sided communication but also an interaction. Interaction brought by virtual environment can be said to show its impact on process of socialization of individuals. Now, situations of socialization, which are addressed as four primary factors, have started to be influenced by virtual environments. Domestic communication started to take different dimensions after inclusion of virtual things. Now, relationships among husbands and wives, children and parents and brothers and sisters are experienced different than what was the case before 2000s.

There are cases of domestic relationships where individuals in families cannot find time for each other due to the fact that time to surf in virtual environments has increased. Internet is shown as one of the reasons for divorces in families.

Individuals in families like and comment under photos of each other on Facebook and other virtual networks. This demonstrates that relationships in society starting from the smallest unit of society, to wit families, have started to shift to virtual environment.

Family members, who spend a lot of time in virtual environments, cannot spend time with their families because they feel the need to surf in internet on evenings and communicate by corresponding over different computers when they need to talk even though they are in the same house, signal that relationships have changed.

Education, which provides contribution to socialization, has started to gain new dimensions with having internet in schools, distant education, online courses and actively using virtual environment.

It can be seen that along with friendships in virtual environments, virtual things are now talked about among chats of peers after emergence of the 'generation $\mathrm{Y}$ ' and secondary lives rather than games on streets and neighborhood friendships. In case of being more interested in virtual things, individuals' communication with their surrounding starts to decline (Özdemir \& Usta, 2007).

\section{What is socio virtualization?}

Mass communication devices provide news to people from all over the world in a faster fashion with their virtual spheres and new technological opportunities that they present. People in the world started to communicate as if they were living in the same neighborhood with opportunities of internet and mass communication devices (IMEF, 2011). People, who receive news and know the world well, can struggle to receive news related to neighborhoods in which they live. The Arab Spring and the Gezi Park events can be shown as examples for power of interaction, which also emerged in virtualization. Impact of the case of 'sociovirtualization', which demonstrates its functionality in each of socialization instruments, is observed in socialization factors (Kurt, 2012). Now, virtual networks have turned into instruments of socialization for kids and young people (Feng \& Xie, 2014). After social relationships and interactions have started to shift to virtual environments, a socio-virtual situation has begun to emerge. Individuals spending more time in virtual environments, increasing communication, information share and opportunities such as telecommunication steer society to a situation of socio-virtualization. Based on this, socio-virtualization can be described as individuals turning from interaction environment in society to virtual environment, spending their time there, as a decline in their interaction with things possessed by society such as customs, traditions and values that are related to society that individuals 
would have learned by living in society and individuals going on with their lives in society by seeing the things that are owned and are not owned by society together with an influence by virtual environments (Kurt, 2012; Kurt, 2013).

Individuals, who resemble to society in every stage of their life and who are socialized by acting like other people in society, started to spend a certain part of their time in socio-virtual environments. It can be said that individuals, who have started to experience sociovirtualization as well as social environments in society, have found occupations that they can spend time in individual sense. We can add many activities in this process ranging from their profession, researches conducted, their will to spend their time well to making new friends and actively using communication and correspondence. Individuals, who begin to be sociovirtualized, are able to find various occupations and activities as well as a place for themselves in virtual world with network connections and 'senses and feelings of networks'. Some cases such as further decreasing of communication and weakening of relationships can emerge when individuals, who are not able to spend their time with society and other individuals as much as they are used to, start to spend this time in virtual environments. Examination of generations distinctly from each other such as $\mathrm{X}, \mathrm{Y}$ and $\mathrm{Z}$ in a research conducted in the literature can be shown as an example of this (Brenner, 1997; Kraut et al., 1998; Prensky, 2001).

It can reveal situations for slowing down values, which are culturally owned by society and transferred to other generations, in this process or differential perceiving among individuals. One of its reasons can be given that participation in social activities and spheres as much as in the past differs in terms of individuals spending time in virtual environments. Also, if individuals start to regard virtual environment as a sphere in which they have no responsibility and feel more comfortable when they feel pressurized by society, this can even further increase shifts from social to socio-virtual.

Studies conducted in the literature are mostly researches about socialization, virtual environments and what generations do with technology and how they are affected by it. Socio-virtualization is a new outlook from the perspective of presence of socialization in virtual environments and new generations beginning to see cultural elements in virtual environments. In this regard, socio-virtualization is important with regard to being an indicator for emergence of differences because of influence of virtual environment along with decreasing time spent with society while individuals are socialized in society. The ones who would like to understand society, researches who try to understand direction and to which direction interests and needs shift, business world, each institution and organization which would like to sell their products and to which direction society is moving and how needs and wills are and will be shaped as well as every researcher can need this scale. Because, measuring turning to what is virtual with regard to needs, wills and desires of humans will provide various opportunities to product owners, the ones who want to understand individuals and to the ones who research society's tendencies. Also, each area in society having their equivalent in virtual environment by considering that environment and somehow embracing the things that belong to society are important for contemplating on this situation. For instance, beginning to use portals, platforms or web sites where importance of norms, values and communication, importance of language spoken by society and rules will be present, lived or repeated would be the case.

In terms of education, considering learning education-related things by shifting towards 
virtual environments, emergence of new options would be the case for managers and instructors. Knowing students' needs (attention, need, personalities and expectations) is important in terms of effectiveness of learning-teaching process and its determination in a more realistic and efficient way in terms of teaching design. Educational needs, teaching goals, course content, structure, learning and teaching process, measurement and assessment approaches can be different for individuals whose socio-virtualization levels differ.

It can be said that determining levels of individuals (students) regarding socio-virtualization is important for making teaching activities and these approaches more effective and this scale can be used in this framework. In short, next steps can be taken by measuring tendency of people towards virtual things for every case, incident and object which are wanted to be shown, taught, embraced and promoted with social life and education remaining under influence of virtual environment.

\section{Method}

\subsection{Study Group}

294 young individuals, most of them are university students, who are living in the center of Konya district, constitute study group of this research. Of all individuals, who participated in the study, 203 are females and 78 are males. 13 participants did not specify their genders. 96 of all participants, who attended this study, are in the age range of 19 and below and 186 of them are in the age range of 20 and 29.12 individuals did not specify their ages.

\subsection{Process of Developing the Scale}

First of all, a pool of items were attempted to be generated in this process of developing the scale. First of all, literature review was conducted in process of developing the scale, socialization (Plummer 2010; Aluja \& Blanch, 2004; Jarvis, 1983; Marshall, 1999; Evkuran 2009; Celkan,1991; Ozankaya 1986; Zeichner \& Tabachnick, 1985; Güvenç, 1995; Josept, 1994; Özgüven, 1996; Coser, 1987, Parke at al., 2008; Dönmezer,1984; Doğan, 2012) and general characteristics of virtual environments (Erturgut, 2008; Binark \& Bayraktutan, 2008; Özdemir \& Usta, 2007; Feng \& Xie, 2014; Altun, 2008; Dunne, Lawlor \& Rowley, 2010; Chana \& Dicianno, 2011; Goldberg, 1997; Young \& Rodgers, 1998; Davis, 2001; Davis, Flett \& Besser, 2002; Mittal, Tessner \& Walker, 2007; Shapira, et al., 2000; Yang, et al., 2005; Nie, Hillygus, \& Erbring, 2008; Rainie, Purcell, \& Smith, 2011) were tried to be determined. A questionnaire research was performed within the framework of specified general characteristics and how perceptions of individuals, who participated in the questionnaire, between socialization and virtual environment are was examined with four open ended questions (Kurt, 2013). In the framework of these questions, answers of open ended questions were tried to be categorized under each question. Obtained texts were examined, students' opinions were made items for behavior and pool of items began to be generated. Items of socio-virtualization scale were determined by making various grammar and vocabulary corrections without changing originality of answers given by individuals. A draft scale of 30 items was put forward within the framework of answers given by 100 respondents to four open-ended questions. For instance, one of the mostly preferred items among answers to the question "Do you think that social relations have changed with use of internet? If you do, could you explain in what direction did a differentiation occur?" was "I do think that it has differed. People prefer internet instead of spending time together and this 
considerably weakens human relations". This answer appeared in the scale as "I prefer internet instead of spending time with people in social life". Again similarly, an open-ended question "Would you think that your interaction and communication with your surrounding have changed after you started to use internet" was answered by most participants as "I do not very actively use internet. However, when I spend time in internet, my communication with family members considerably comes to a halt. I live detached from home without knowing what is happening at home and who is coming to our home." and this answer appeared in the scale as "I cannot really sit with my family much since I feel the need to surf in internet on evenings at home".

A pool with 30 items was generated with contributions from field experts and information obtained from the literature. Choices with five levels were placed opposed to generated items to determine self-sufficiency levels of individuals that were stated in items. These choices were organized and scored as "(1) never", "(2) rarely", "(3) sometimes", "(4) generally" and "(5) always". Items, which were created as drafts, were examined by an expert on Turkish language, two field experts on educational technology and a psychological consultancy and counseling expert in terms of their content, expression, meaning, grammar and punctuation errors. Necessary adjustments were made in line with pointed criticisms and draft scale with 20 items was generated. This draft scale was applied on study group on the basis of voluntarism. Gathered data were loaded to the SPSS software 15.007 to perform reliability and validity analyses of the scale from statistical ways.

\subsection{Data Analysis}

Whether to perform a factor analysis was determined by firstly conducting KMO and Bartlett's test on gathered data from the scale in the framework of statistical analyses in order to determine structural validity of this scale. Based on obtained values, exploratory factor analyses were performed on data; case of dividing the scale into factors was determined with principal components analysis and their factor loads were examined by using Varimax orthogonal rotation technique. Factor analysis is used in order to reveal whether items in a scale have been divided in fewer factors (Balc1, 2009). On the other hand, as a result of principal components analysis used in factor analysis, items whose factors loads were below 0.30 and items, which did not have a 0.100 difference at least between their loads in two factors in other words items whose loads were spread to two factors, should be omitted (Büyüköztürk, 2002). As a matter of fact, factor loads of items in the scale being higher than 0.30 and explaining $40 \%$ of general variance is deemed sufficient in terms of behavioral sciences (Kline, 1994; Scherer at al., 1988). The main criterion in evaluating results of factor analysis is factor loads (Balc1, 2009; Gorsuch, 1983). Factor loads being high is seen as an indicator that variable can appear below the said factor (Büyüköztürk, 2002). Additionally, it is argued that calculating common factor variance is important in terms of multi-factorial patterns in particular and it is described as common variance that factors create on each variable as a result of factor analysis (Çokluk et al. 2010).

Validity character of the scale was determined by testing item distinctiveness powers of remaining 14 items as a result of factor analysis and item-total correlations via Pearson's $r$ test. Finding a correlation between scores obtained from each item and scores obtained from factors to which items belong is used as a criterion in terms of understanding factors' level of serving their general purpose (Balc1, 2009). Internal consistency coefficients and stability tests were conducted in order to determine reliability of the scale. Cronbach's alpha reliability 
coefficient was used for determining internal consistency level. Reliability coefficient being 0.70 and higher is acknowledged as an indicator of this scale's reliability (Büyüköztürk, 2002; Gorsuch, 1983). The scale's stability level was calculated in the form of determining correlation between two application results performed with four weeks interval. Reliability coefficient, which represents level of consistency, rises as it approaches to 1.00 and falls as it approaches to 0.00 (Gorsuch, 1983). As is known, in general the level 0.00-0.39 signifies that there is low correlation; the level 0.30-0.70 signifies that there is medium-level correlation and the level 0.70-1.00 signifies high correlation (Büyüköztürk, 2002).

\section{Findings}

Operations conducted in the framework of reliability and validity analyses of the scale and findings are presented below.

\subsection{Findings on Validity of the Scale}

Structural validity and item-total correlations were examined within the framework of validity of the Socio-Virtualization Perception Scale (SVPS) and findings are presented as follows:

\subsubsection{Structural Validity}

First, Kaiser-Meyer-Olkin (KMO) and Bartlett's test analyses were performed on data to test structural validity of the SVPS and KMO was designated as 0.856 and value of Bartlett's test was specified as $\chi^{2}=2747,48 ; \mathrm{sd}=435(\mathrm{p}=0,000)$. It was understood that factor analysis can be performed on the scale with 20 items within the framework of abovementioned values.

In the first stage, principal components analysis was conducted to determine whether the scale is one-dimensional. Because, principal components analysis is a very frequently used technique as a technique of factorization (Büyüköztürk, 2002). Then, Varimax orthogonal rotation technique was used according to principal components. In this line, after omitting 6 items, whose item loads were below 0.30, from the scale, another factor analysis was performed on remaining items. There is no item in the scale, whose load is spread to two factors. Resulting pool of items were again examined by two educational technologists to ensure that scope validity would not be disrupted due to omitted items. Thanks to opinions of field experts on that these six omitted items would not affect scope validity, other analyses were able to be performed.

It was observed as a result of these operations that a total of remaining 14 items in the scale were clustered under two factors. KMO value of the 14-item scale with its final form was determined to be 0.860 and its Bartlett's test values were determined to be $\chi 2=1495,124$; $\mathrm{sd}=91 ; \mathrm{p}<0,001$. It was observed that non-rotated factor loads of remaining 14 items in the scale were between 0.427 and 0.693 ; on the other hand, these loads were between 0.669 and 0.830 in its rotated form after Varimax orthogonal rotation technique. On the other hand, it was stated that items and factors that were included in the scope of this scale explained $51.49 \%$ of total variance. As is known, factor loads not being below 0.30 and amount of variance explained in terms of behavioral sciences being $40 \%$ are regarded sufficient (Büyüköztürk, 2002; Eroğlu, 2008). Factor names were given by examining contents of items in factors. 9 items were gathered under a factor named as "negativity in communication" and 5 items were gathered under a factor named "social attention in virtualization". 
This situation is also seen in the scree plot graph drawn according to eigenvalues (Figure 1). In figure 1, there are high-momentum drops in the first two factors therefore these two factors had significant contribution to variance but on the other hand, drops in other factors have acquired a horizontal shape, in other words this means that their contribution to variance is similar (Büyüköztürk, 2002; Eroğlu, 2008).

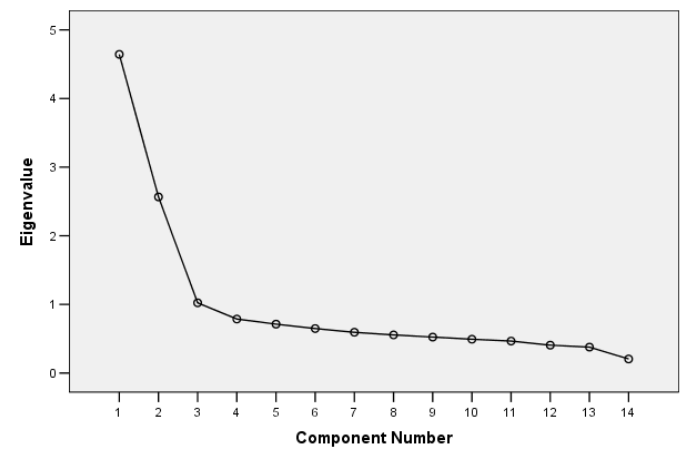

Figure 1. Scree Plot Graph (Eigenvalues according to Factors)

As a result of these operations performed, item loads of remaining 14 items in the scale according to factors, eigenvalues of factors and findings on amounts of variance explanation are provided in Table 1.

Table 1. Results of Factor Analysis of the Scale Conducted according to Factors

\begin{tabular}{|c|c|c|c|c|c|}
\hline \multicolumn{3}{|c|}{ Items } & \multirow{2}{*}{$\begin{array}{l}\text { Common } \\
\text { Variances } \\
, 693\end{array}$} & \multirow{2}{*}{ F1 } & \multirow[t]{2}{*}{$\mathrm{F} 2$} \\
\hline \multirow{9}{*}{ 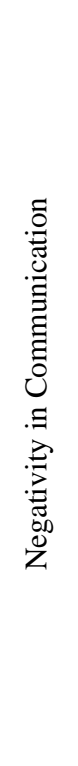 } & M16 & $\begin{array}{l}\text { People started to mostly establish virtual friendships, withdrew } \\
\text { into themselves and turned into asocial virtual people. }\end{array}$ & & & \\
\hline & M17 & $\begin{array}{l}\text { People are unaware of each other in real life and they started to } \\
\text { live very connected to virtual environment. }\end{array}$ & ,638 &, 799 & \\
\hline & M27 & $\begin{array}{l}\text { Most people in fact became asocial in real life. They go on } \\
\text { with their lives in social networks. }\end{array}$ &, 517 &, 718 & \\
\hline & M20 & $\begin{array}{l}\text { Since they use internet a lot, I think that people expressing } \\
\text { their feelings and thoughts in daily life has become } \\
\text { complicated. }\end{array}$ &, 518 &, 715 & \\
\hline & M14 & $\begin{array}{l}\text { I think that now what people share with each other has } \\
\text { decreased. }\end{array}$ &, 542 &, 707 & \\
\hline & M15 & $\begin{array}{l}\text { People give their secrets to people whom they do not know at } \\
\text { all in virtual environments rather than talking with people in } \\
\text { their surroundings. }\end{array}$ & ,458 & ,671 & \\
\hline & M21 & $\begin{array}{l}\text { I think that there are people, who cannot leave computers, do } \\
\text { not know what is going on in family environment and have } \\
\text { lives detached from their families. }\end{array}$ & ,427 & ,654 & \\
\hline & M23 & $\begin{array}{l}\text { People are able to establish communication over internet more } \\
\text { easily but this situation complicates face-to-face } \\
\text { communication. }\end{array}$ & ,433 & ,641 & \\
\hline & M13 & We've started to lose our cultural values because of internet. & 411 & 617 & \\
\hline \multirow{4}{*}{ 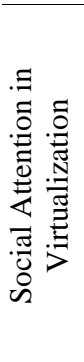 } & M19 & $\begin{array}{l}\text { The time I spend with people becomes limited unavoidably } \\
\text { because of internet. }\end{array}$ &, 558 & &, 731 \\
\hline & M7 & $\begin{array}{l}\text { When I spend time in internet, my communication with family } \\
\text { members considerably comes to a halt. I live detached from } \\
\text { home without knowing what is happening at home and who is } \\
\text { coming to our home. }\end{array}$ &, 520 & & ,712 \\
\hline & $\mathrm{M} 2$ & $\begin{array}{l}\text { I cannot really sit with my family much since I feel the need to } \\
\text { surf in internet on evenings at home. }\end{array}$ &, 529 & & ,704 \\
\hline & M3 & $\begin{array}{l}\text { I prefer internet instead of spending time with other people in } \\
\text { social life. }\end{array}$ & ,513 & & ,688 \\
\hline
\end{tabular}




\begin{tabular}{llll}
\multirow{2}{*}{ M18 } & $\begin{array}{l}\text { I delay responding when my mom calls to me while I am } \\
\text { playing games on internet. }\end{array}$ &, 452 &, 669 \\
\hline Eigenvalue & 4,637 & 2,572 \\
Explained variance & 33,122 & 18,374 \\
\hline
\end{tabular}

As seen in Table 1, the scale's "negativity in communication" factor contains 9 items and factor loads vary between 0.830 and 0.617. Eigenvalue of this factor in general scale is 4.637; amount of contribution it provides to general variance is $33.122 \%$. The factor "Social Attention in Virtualization" contains 5 items. Factor loads of items are between 0.731 and 0.669 . Eigenvalue of this factor in general scale is 2.572 ; amount of contribution it provides to general variance is $18.374 \%$.

\subsubsection{Item Distinctiveness}

In this section, scores obtained from each items in factors according to item-total correlation method and correlations among scores obtained from factors were calculated, and item distinctiveness levels in other words each items' levels for serviceability to general purpose were tested. Item-factor correlation values obtained for each item are provided in Table 23.

Table 2. Correlation Analysis of Item-Factor Scores

\begin{tabular}{llll}
\hline \begin{tabular}{c} 
F1 \\
Comativity in \\
\multicolumn{1}{c}{ Communication) }
\end{tabular} & \multicolumn{2}{c}{$\begin{array}{c}\text { F2 } \\
\text { Social Attention in } \\
\text { Virtualization) }\end{array}$} \\
\hline $\begin{array}{llll}\text { Item } \\
\text { No }\end{array}$ & $\mathrm{r}$ & Item No $\mathrm{R}$ \\
\hline M16 &, $813(* *)$ & M19 &, $742(* *)$ \\
M17 &, $784(* *)$ & M7 &, $715(* *)$ \\
M27 &, $714(* *)$ & M2 &, $684(* *)$ \\
M20 &, $713(* *)$ & M3 &, $668(* *)$ \\
M14 &, $712(* *)$ & M18 &, $713(* *)$ \\
M15 &, $686(* *)$ & & \\
M21 &, $660(* *)$ & & \\
M23 &, $643(* *)$ & & \\
M13 &, $642(* *)$
\end{tabular}

As seen in Table 3, item test correlation coefficients vary between 0.813 and 0.642 for the first factor and 0.742 and 0.668 for the second factor. Each item is in a significant and positive relationship with the whole factor $(\mathrm{p}<0.000)$. These coefficients are validity coefficients of each item and they refer to consistency with the whole scale in other words the level of serviceability to general purpose of the scale (Yüksel, 2009; Carminesi \& Zeller, 1982).

\subsubsection{Item Distinctiveness}

Distinctiveness power of items in the scale was estimated. For this purpose, first raw scores obtained from each item were sorted from smaller to greater, then lower and upper groups with 80 people each that constitute the group at lower $27 \%$ and the group at upper $27 \%$ were determined. T-test values of independent groups were calculated over their total scores in groups. $\mathrm{T}$ values related to their distinctiveness power and findings related to their levels of significance are provided in Table 3. 
Table 3. Item Distinctiveness Powers

\begin{tabular}{llll}
\hline $\begin{array}{c}\text { (Negativity in } \\
\text { Communication) }\end{array}$ & \multicolumn{2}{c}{$\begin{array}{c}\text { F2 } \\
\text { (Social Attention in } \\
\text { Virtualization) }\end{array}$} \\
\hline Item & t & Item & T \\
\hline M16 & 13,126 & M19 & 6,710 \\
M17 & 13,093 & M7 & 6,282 \\
M27 & 14,187 & M2 & 6,194 \\
M20 & 12,388 & M3 & 5,419 \\
M14 & 11,233 & M18 & 5,294 \\
M15 & 11,233 & F1 & 23,249 \\
M21 & 11,269 & F2 & 6,690 \\
M23 & 11,757 & Total & 32,293 \\
M13 & 9,578 & df: $\mathbf{1 5 8} ; \mathbf{p}<, 001$ \\
\hline
\end{tabular}

It is observed in Table 4 that independent sample t-test values related to 14 items, factors and total score in the scale vary between 13.126 and 5.294. $\mathrm{T}$ value for the whole scale was determined as 32.2963. Level of each difference determined is significant $(p<0.001)$. Accordingly, it can be said that distinctiveness of both the whole scale and each item is high.

\subsection{Findings regarding Reliability of the Scale}

Internal consistency and stability analyses were performed on data to calculate reliability of the scale. Performed operations and findings are presented as follows:

\subsubsection{Internal Consistency Level}

Reliability analysis of the scale for its factors and entirety was estimated by using Cronbach's Alpha reliability coefficient. Reliability analysis values related to each factor and the whole scale are summarized in Table 4:

Table 4. Results of Reliability Analysis on Factors and the whole Scale

\begin{tabular}{lll}
\hline Factors & $\begin{array}{l}\text { Number } \\
\text { of Items }\end{array}$ & $\begin{array}{l}\text { Cronbach's } \\
\text { Alpha }\end{array}$ \\
\hline Negativity in Communication & 9 &, 873 \\
Social Attention in Virtualization & 5 &, 744 \\
Total & 14 &, 795 \\
\hline
\end{tabular}

As seen in Table 3, Cronbach's Alpha reliability coefficient of the scale that consists of 2 subfactors and a total of 14 items was determined as 795. On the other hand, Cronbach's Alpha values regarding factors are 0.873 and 0.744 respectively. Accordingly, it can be said that internal consistency of the scale is pretty high.

\subsubsection{Stability Level of the Scale}

Stability level of the scale was detected by using test-retest method. As is known, a reliable measurement tool should be able to make stable measurements (Balc1, 2009). The 14item final form of the scale was re-applied on 41 individuals, on whom this application was performed, four weeks later. Relationship between scores obtained as a result of both applications was evaluated in terms of both each item and the whole scale. Thus, ability to make stabile measurements for an item that is present in the scale as well as for the whole scale was tested. Findings were summarized in Table 5. 
Table 5. Test-Retest Results of Items in the Scale

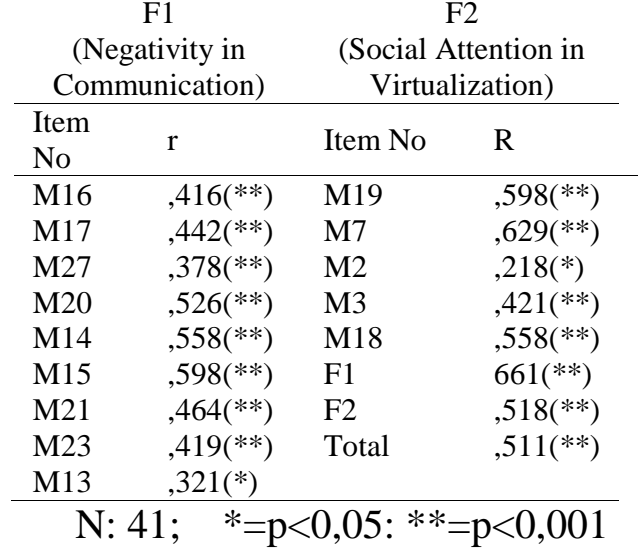

It is seen in Table 4 that correlation coefficients of each item which were obtained via testretest method vary between 0.218 and 0.629 and each relationship is significant and positive. It is observed that correlation coefficients obtained via test-retest method for factors that constitute the scale are 0.661 and 0.518 respectively and each relationship is significant and positive. Correlation coefficient for the whole scale is 511. As is known, reliability is related to stability, consistency and sensitivity characteristics of a scale. For this reason, these values that were determined as stability coefficient are considered as an evidence for existence of reliability of this scale (Hovardaoğlu, 2000). Accordingly, it can be said that the scale can make stable measurements.

\section{Conclusion}

In this study, a scale was developed in order to determine individuals' perceptions towards socio-virtualization. The SVPS is a 5-item Likert type scale and consists of 14 items that can be grouped under two factors. Each item that is present in factors was scaled as never (1), rarely (2), sometimes (3), generally (4) and always (5). Validity of the scale was examined with two different methods. These are methods of testing validity through (1) factor analysis and (2) distinctiveness characteristics.

According to exploratory factor analysis results, the scale consists of two factors. Considering factor loads of items in factors, eigenvalues of factors and explained variance ratios, it can be said that the scale is a scale with structural validity. Item factor correlations were calculated on data to determine to what extent each item in the scale can measure characteristics that are attempted to be measured with their relevant factor. It can be said according to obtained values that each item and each factor that is present in the scale significantly serve the purpose for being able to measure desired characteristic that is sought to be measured with entirety of the scale, and each item is distinctive at a desired level. Relevant literature was reviewed for the purpose of establishing the scale's reliability of criterion (for present or similar scales); reliability for similar scales could not be calculated since a similar scale could not be found with regard to content and objective.

The scale's internal consistency coefficient was estimated by using Cronbach's Alpha formula. It can be said that the scale can make reliable measurements within the framework of these calculated values. Test-retest method was applied to determine time-dependent stability level of the scale by using data gathered in applications that were performed in four weeks intervals. Test-retest method was calculated for each item and also within the framework of 
sub-factors of the scale. All items that are present in the scale are in medium-level correlation according to calculated correlation coefficients. Accordingly, each item and each factor can make stable measurements from the aspect of time-dependent stability.

Factors in the scale were named as "Negativity in Communication" and "Social Attention in Virtualization" in a way that will reflect general characteristics of items that were gathered under these factors. 9 items were grouped under the factor named "Negativity in Communication" and 5 items were grouped under the factor named "Social Attention in Virtualization".

The factor named "Negativity in Communication" that consists of 9 items was demonstrated as that in general, people in social life go on with their life in constant communication but virtual environment makes their communication with their families in particular and surrounding decline, weaken and lose sincerity. Accordingly, the factor's name represents a situation which signifies that communication is moving toward negativity. Albeit participants stated that their communication in social life is different than communication in virtual environment, they also argued that it is also the case that real communication would decline and be damaged. Individuals, who do not somehow feel comfortable in terms of social life, find opportunity to turn to communication and interaction in environments where they feel more comfortable with social networks (Altun, 2008; Dunne, Lawlor \& Rowley, 2010; Chana \& Dicianno, 2011). As a result of this communication and interaction, individuals think that they express themselves more comfortably in virtual environments rather than in social reality by moving away from sociality. And this demonstrates their turn to a situation where they can get things in virtual environments that they would have gotten in society, in other words socio-virtualization with a decline in communication and interaction in terms of socialization.

Despite many beneficial aspects of communication technologies that present numerous conveniences for people, it is possible to say that their negative effects are also witnessed (Khasawneh \& Al-Awidi, 2008). Numerous studies were performed that have examined issues such as particularly using virtual environment more with developing technology, individuals' shift mostly towards individual things by starting to move away from social life, understanding negative and positive situations regarding their socialization and declining communications of individuals with society (Goldberg, 1997; Young \& Rodgers, 1998; Davis, 2001; Davis, Flett \& Besser, 2002; Mittal, Tessner \& Walker, 2007).

It would be the case that communications of individuals, who express that they feel more comfortable in virtual environment rather than in social life, in real life would be negatively affected due to their extensive use of virtual environments (Shapira, et al., 2000; Yang, et al., 2005). Activities of spending more time in virtual environment and utilizing virtual environment more create various negativities in social relationships. As a result, these situations in virtual environment can be argued to have negatively affected communication and relationships in real life ( Nie, Hillygus, \& Erbring, 2008; Rainie, Purcell, \& Smith, 2011).

Increasing use of internet and having effectiveness on adolescents as much as their social life also influences familial relationships of individuals. In a research conducted on relationship between family and internet, it was detected that children do not have same opinions with their parents on issues related to internet (Kuzu, 2011). It was found that as time that parents spend for using internet increases, domestic and face-to-face communication decline. This 
situation is another point that was detected to be also valid for children whose use of internet has increased. Decreasing face-to-face communication because of internet has also multiplied domestic conflicts. In other words, individuals replace the process of socialization, which they will experience via information that will be obtained from their family and surrounding, with their relationships established in virtual environment (Kelleci, 2008).

It was found in another research performed (Horman et al., 2005 ) that social developments of children who spend most of their time with computer games considerably regress, selfconfidence of these children is low and their social anxiety levels and aggressive behaviors increase. In another study conducted (Colwell et al., 2000), a negative relationship was detected between time to spend playing games in computer and self-confidence. This factor was called "Negativity in Communication" since interaction and face-to-face communication among individuals decline with a decrease in activity and activeness of individuals in society and in general, this aspect was emphasized in participants.

Answers given considering situations such as spending time in virtual environments, moving away from places in social life and delaying responsibilities and what to dos in real life were gathered under the factor "Social Attention in Virtualization" that consists of 5 items.

Socialization of new generation individuals, who are particularly referred with various names today, is important in terms of analyzing impact of virtual environments on newly growing individuals and understanding them (Prensky, 2005; Odabaş1, 2009; Palfrey \& Gasser, 2008). Contemporary individuals, who know that all opportunities of virtual environment are in their hands, take all information whether to be used or not and confuse everything due to constantly receiving information, needs, wills and desires in time, can be influenced by virtual attraction rather than social one. Because, while social life draws a limit with its morals, values and rules, these limits do not exist in virtual environment. Social attentions of individuals shifting towards socio-virtualization in these aspects would be the case. It can be argued that virtual interests of individuals who have relationships and responsibilities in society are higher due to the fact that virtual environment is different than social life in terms of relationships and responsibilities. And this case causes them to move away from sociality.

It is stated that individuals, who have started to spend more time in virtual environments, get distant from social life, their social relations are weakened and their communication with their family and surrounding declines (Şan \& Hira, 2005). Thus, virtual environments' aspects that are influential for individuals are more preferred with their characteristics such as getting in touch without communication and entertainment (Morahan-Martin, 1999).

With time spent with people getting limited unavoidably because of internet and considerable disruption of communication within families, family members, who are sometimes not aware what is going on in their house, can prefer virtual environments rather than spending time with people in social life. What is experienced in virtual environments is mostly shaped and used within the framework of individuals' needs (Johnson, 2001).

Today, new generation which grows along with technological opportunities is called "Generation Y" and its attributes are analyzed by investigating it from every aspect (Brenner, 1997; Stoll, 1995; Turkle, 1996; Kraut et al., 1998; Prensky, 2001). Attributes and opportunities of generation $\mathrm{Y}$ are further above what societies present to them in our day and they are in a position that mostly commands material side of culture. They have a nature which likes competition individually and which commands communication technologies 
thanks to what elements of material culture have added to them, which prioritizes their interests, wants to live more free, sees desires and wills as needs and wants to stay away from social responsibility. In this regard, they remain in a position that sits between concepts of socialization and socio-virtualization and that should be investigated and examined from many more aspects. Compared to previous generation, Generation $\mathrm{Y}$ is more prone to modern educational platforms and uses internet at a higher rate (TUIK, 2007). Name of this factor was designated as "Social Attention in Virtualization" due to referring generations with different names influenced by technology, shifting what is experienced in social life to virtual environments, creation of similar situations like social life with platforms such as secondlife and spending more time in virtual environments.

After starting to re-shape and re-organize individual and social things in terms of present day, perceptions, habits, needs, wishes and desires have also begun to change. Newly-raised generations, particularly with generation "Y", growing with technology and looking at life and society a little bit different than previous generations distinguish them with various attributes. Among them, receiving education, differentiation of occupational groups and situations like knowledge, ability, attitude and behaviors of required employed personnel can now be perceived differently for social life. For instance, today, people might not have to go to work. They can also stay at home by tracking their jobs from virtual environment. Another example is that we do not have to mesh into society to do shopping. If desired, one can do shopping in virtual environment. Also, while using internet in education and performing distant education is taken for granted for new generation, it can be seen as a different situation that is difficult to get used to for previous generations. Considering examples given so far, they were given as examples to works and activities that are performed in virtual environments distant from social life. Thus, individuals are mostly occupied with sociovirtual things rather than social things, virtual environment can now be witnessed in every aspect of life and its effect is somehow the case (Hamburger \& Ben-Artzi, 2003). With developing technology and age of information, design types to be determined for new generation, putting forward attributes in terms of goals, and results and continuity of information and skills to be learned in terms of teaching and learning process have a great importance ( Friend \& Bursuck, 2002; Slavin \& Cheung, 2004; Keller, 2007).

When the SVPS is considered in terms of newly growing generation and its needs regarding perceiving and experiencing social life, existence of virtual environment that now manifests its impacts in every area of life and that has somehow a contact in life should not be ignored. Every area ranging from family, education, peers to social environment, shopping, mass communication devices, business and entertainment environments has somewhat gained a different dimension after inclusion of virtual environment into the equation. In this regard, it should not be forgotten that the SVPS will provide contribution to analyzing the abovementioned social environments, will aid understanding curricular and extra-curricular situations from the aspect of needs, knowledge, ability and wishes of learners and might also help clearing topics that should be taken into consideration for planning teaching activities. However, due to the fact that this concept is quite new, dimensions of impacts of virtual environments on areas which are factors of socialization such as family, education, peers, media, environment, religion and etc. have not been researched. Topics such as in what environments, to what extent, how and why does socio-virtualization dimension of socialization occur after virtual environment will be areas of research for future years. In this context, researching impacts of socio-virtualization on socialization factors and on different variables in changing and shrinking new world can be suggested. 
Consequently, it can be said that the SVPS is a reliable and valid scale that can be used for determining perception levels of individuals towards socio-virtualization. No reliable and valid measuring tool could be encountered in the literature that covers cases related to socialization by utilizing values, norms and culture that remain between socialization and virtual environments for individuals in particular. Therefore, it can be considered that this measurement tool can provide important contributions to the literature. However, ages of majority of study group, through which reliability and validity studies of measurement tool were executed, is around 25 and it generally consists of students. Repeating validity and reliability studies of the scale on different age and occupational groups can be suggested to overcome this limitation. Also, all items of the scale factors named "Negativity in Communication" and "Social Attention in Virtualization" are negative. All factor loads of these items are negative. Using this scale by taking this situation into account or re-checking reliability and validity by converting items to positive while using the scale in another research can be suggested.

\section{References}

Altun, M. B. (2008). Siber gerçeklikte kültür and iletisim sorunları. Yayımlanmamıs yüksek lisans tezi [Cyber culture and communication problems in reality. Unpublished Master's thesis]. Marmara Üniversitesi Sosyal Bilimler Enstitüsü. [Marmara University Social Science Institute].

Aluja, A., Blanch, A.,(2004). Socialized personality, scholastic aptitudes, study habits, and academic achievement: exploring the link European Journal of Psychological Assessment, 20 (3) (2004), pp. 157-165

Balc1, A. (2009). Sosyal bilimlerde araştırma: Yöntem, teknik and ilkeler[Research in social science: Methods, techniques and principles]. Ankara: PegemA Yayınevi [PegemA Pub.].

Binark, M. \& Bayraktutan-Sütcü, G. (2008). Silkroad Online'da Sanal Cemaat İnşası and Türk Klan Kimliği [Building Virtual Community in Silkroad Online and the Turkish clan Identity]. inet-tr'08 - XIII. Türkiye'de İnternet Konferansı Bildirileri [Proceedings of Internet inTurkey Conference], Ankara, 22-23 December. Orta Doğu Teknik Üniversitesi [Middle East Technical University], pp.133.

Brenner, V. (1997). Psychology of computer use: XLVII. Parameters of Internet use, abuse and addiction: the first 90 days of the Internet Usage Survey. Psychological Reports, 80, pp. 879-882

Büyüköztürk, Ş. (2002). Sosyal bilimler için veri analizi el kitabı [Handbook for Social science data analysis]. Ankara: PegemA Yayınevi [PegemA Pub.].

Carmines, E.G, Zeller, R. A. (1982). Reliability and validity assessment. $5^{\text {th }}$ ed. Beverly Hills: Sage Publications Inc.

Celkan, H.Y.(1991), Eğitim Sosyolojisi [Sociology of Education], Atatürk Üniversitesi Yayınlar1 [Ataturk University Pub.], Erzurum.

Chana, W. M., Dicianno B. E. (2011).Virtual socialization in adults with spina bifida. $P M \& R$, Volume 3, Issue 3, Pages 219-225

Colwell J, Payne J.( 2000). Negative correlates of computer game play in adolescents. British Journal of Psychology, 91: 295-310.

Coser, L. \& Nock, S. \& Steffan, P. \& Rhea, B. \& Merton(editor), R. (1987) Introduction To Sociology, Second Edition, USA

Çokluk, Ö., Şekercioğlu, G., Büyüköztürk, Ș. (2010). Sosyal bilimler için çok değişkenli istatistik: Spss and Lisrel uygulamalarl [Multivariate statistics for the social sciences: SPSS and LISREL applications]. Ankara: PegemA Yayınevi [PegemA Pub.]. 
Dais, R. A. (2001). A cognitive-behavioral model of pathological internet use. Computers in Human Behavior, 17,187-195.

Davis,R. A., Flett, G. L., \& Besser, A. (2002). Validation of a new scale for measuring problematic internet use; implications for pre-employment screening. Cyber Psychology and Behavior, 15, 331-347

Doğan, İ.(2012), Eğitim Sosyolojisi [Sociology of Education], Nobel Yayın Dağıtım, 2.Baskı [Nobel Pub., 2nd Edition].

Doğan, N.(1993), İlk and Orta Dereceli Okul Ders Kitapları and Sosyalleşme (1876-1918) [Primary and Secondary School Textbooks and Socialization (1876-1918)], Bağlam Yay. [Bağlam Pub.], Ankara

Dönmezer S., (1984) Sosyoloji [Sociology], Savaş Yayınları [Savaş Pub.], Ankara

Dunne, A., Lawlor, M., Rowley, J. (2010). Young People's Use of Online Social Networking Sites Uses and Gratifications Perspective. Journal of Research in Interactive Marketing, Vol. 4, pp.46-58.

Eroğlu, A. (2008). Faktör analizi [Factor analysis]. Ş. Kalaycı (Ed.), SPSS Uygulamalı çok değişkenli istatistik teknikleri [](ss. 321-331) [SPSS Applied multivariate statistical techniques]. Ankara: Asil Yayın Dağıtım [Asil Pub.].

Erturgut, R. (2008). İnternet Temelli Uzaktan Eğitimin Örgütsel, Sosyal, Pedagojik and Teknolojik Bileşenler [Internet Based Distance Education's Organizational, Social, and Technological Pedagogical Components]. Bilişim Teknolojileri Dergisi, 1, 2 [Journal of Information Technology, 1, 2]

Evkuran, M.(2010), Değerler Eğitimi and Eğitimde İdeoloji Sorunu [Values Education and Ideology Problem in Education], Uluslar arası Eğitim Felsefesi Kongresi [International Congress of Philosophy of Education], 6-8 March, Eğitim Bir-Sen, Ankara, pp. 479-488.

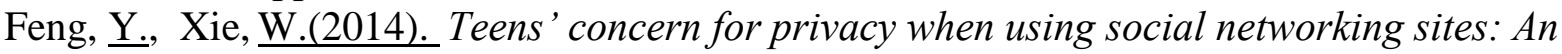
analysis of socialization agents and relationships with privacy-protecting behaviors. Computers in Human Behavior Volume 33, April, Pages 153-162

Friend, M., \& Bursuck, W. (2002). Including students with special needs ( $3^{\text {rd }}$ ed.). Boston, MA: Allyn \& Bacon.

Goldberg, I. (1997). Ivan Goldberg discusses "Internet addiction". http://www.psycom.net/ Accessed 03.09.2013.

Gorsuch, R. L. (1983). Factor analysis. Hillsdale: Lawrence Erlbaum Associates.

Güvenç, B.(1995), Kültür and Eğitim [Culture and Education], Gündoğan Yayınları [Gündoğan Pub.], Ankara.

Hamburger-Amichai, Y., Ben-Artzi, E. (2003). Loneliness and Internet use. Computers in Human Behavior, Volume 19, Issue 1, Pages 71-80.

Horman JP, Hansen CE, Cochian ME, Lindsey CR(2005). Liar, liar: İnternet faking but not freguency of use affect social skills, self-esteem, social anxiety, and aggression. Cyber Psychol Behav., 8(1): 1-6.

Hovardaoğlu, S. (2000). Davranış Bilimleri İçin Araştırma Teknikleri [Research Methods for the Behavioral Sciences]. Ankara: Ve-Ga yay. [Ve-Ga Pub.].

$\operatorname{MEF}(2011)$. http://www.imef.org.tr acces date: 13.03.2014

Jarvis, P., (1983). Professional Education. Croom Helm, London.

Johnson, C. M. (2001). A survey of current research on online communities of practice. Internet and Higher Education, 4, 45-60.

Josept F., Çev Çelebi N., (1994). Sosyoloji Nedir [What is sociology], Atilla Kitapevi [Atilla Pub.], Ankara, 
Kelleci, M(2008). İnternet, Cep Telefonu, Bilgisayar Oyunlarının Çocuk and Gençlerin Ruh Sağlığına Etkileri [Internet, Cell Phones, Computer Games' Effects on Children and Youth's Mental Health], Türk Silahll Kuvvetleri Koruyucu Hekimlik Bülteni [Turkish Armed Forces Preventive Medicine Bulletin] , 7(3):253-256

Keller, J. M., (2007). Motivation and performance. In R. A. Reiser \& J. V. Deinpsey (Eds ), Trends and issues in instructional design and technology ( ${ }^{\text {nd }}$ Ed.) (pp. R2-92). Columbus: Merrill Prentice Hall.

Khasawneh, O. M., \& Al-Awidi, H. M. (2008). The effect of home computer use on Jordanian children: A parental perspective, J. Educational Computing Research, 39(3), 267-284.

Kline, P. (1994). An Easy Guide to Factor Analysis. London and New York: Routledge.

Kraut, R., M. Patterson, V. Landmark, S. Kiesler, T. Mukophadhyay, W. Scherlis. (1998), Internet paradoxa social technology that reduces social involvement and psychological well being? American Psychologist, 53, pp. 1017-1031.

Kurt, İ. ( 2013). Virtualization In Terms of Community from the View of Students' Feedback, Beder University Journal of Educational Sciences, Volume 2, No:1, April, Tirana, Albania.

Kurt, İ. (2012). Toplumsallaşma Sürecinin 'Toplumsanallaşma' Bağlamındaki Yolculuğu. Eğitim Fakültesi Dergisi [Journal of the Faculty of Education], VII,1, June, ISSN:1307-1076, Bayburt Üniversitesi [Bayburt University].

Kuzu, A.(2011). İnternet and Aile [Internet and Family], Aile and Toplum [Family and Society], 7(27):9-31

Marshall, G.(1999). Sosyoloji Sözlüğü [A Dictionary of Sociology], Translator: Osman Akınhay, Derya Kömürcü, Bilim and Sanat Yay [Bilim and Sanat Pub.], Ankara.

Mittal, V. A., Tessner, K. D., \& Walker, E. F. (2007). Elevated social internet use and schizotypal personality disorder in adolescents. Schizophrenia Research, 94,50-57.

Morahan-Martin, J. (1999). The relationship between loneliness and Internet use and abuse. Cyber Psychology and Behavior, 2 pp. 431-440.

Nie, N. H., Hillygus, D. S., \& Erbring, L. (2008). Internet use, interpersonal relations, and sociability: A time diary study. In B. Wellman \& C. Haythornthwaite (Eds.), The internet in everyday life (pp. 215-243). Oxford, UK: Blackwell Publishers Ltd.

Odabaşı, F. H. (2009). 21. yüzyıl öğreneni (Davetli konuşmacı) [21st century learner (Guest speaker)], 25. Yll Etkinlikleri [25th Anniversary Events]: AR-GE Konferans1 [R\&D Conference], 14 March, Ankara: Özel Arı Okulları [Ar1 Private Schools].

Ozankaya, Ö.(1986). Toplumbilim [Social science], Tekin Yayınevi [Tekin Pub.], Ankara.

Özdemir, S. \& Usta, E. (2007) İlköğretim Sınıf Öğretmenliği Öğrencilerinin İnternet Kullanım Amaçlarının İncelenmesine İlişkin Bir Araştırma [A Research on the Investigation of Internet Usage Purposes of Primary School Teacher Candidates]. Türkiye Sosyal Araştırmalar Dergisi [Journal of Social Research in Turkey]. TSA / Year: 11, volume: 3, December.

Özgüven M., (1996). Toplum Bilimlerine Giriş [Introduction to Social Sciences], Ekin Kitapevi [Ekin Pub.], Bursa,

Palfrey, J. and Gasser, U. (2008). Born digital: Understanding the first generation of digital natives. NY: Basic Books.

Parke, R.D., Leidy, M.S., Schofield, T.J., Miller, M.A., Morris, K.L. (2008). Socialization, Encyclopedia of Infant and Early Childhood Development Pages 224-235

Plummer, K.(2010). Sociology: The Basics, Routledge, London.

Prensky, M. (2001). Digital natives, digital immigrants. On the Horizon, 9(5), 1-5.

Prensky, M. (2005). Listen to the natives. Learning in the Digital Age, 63(4), 8-13. 
Rainie, L., Purcell, K., \& Smith, A. (2011). The social side of the internet [Report]. Retrieved February 16, 2011 from Pew Internet \& American Life Project http://www.pewinternet.org/ /media//Files/Reports/2011/PIP_Social_Side_of_the_Int ernet.pdf.

Scherer, R. F., Wiebe F. A., Luther, D. C. and Adams J. S. (1988). Dimensionality of Coping: Factor Stability Using the Ways of Coping Questionnaire, Psychological Reports 62(3), 763-770. PubMed PMID: 3406294.

Shapira, N. A., Goldsmith, T. D., Keck, P. E., Khosla, U. M., \& McElroy, S. L. (2000). Psychiatric features of individuals with problematic internet use. Journal of Affective Disorders, 57,267-272.

Slavin, R. E., Cheung, A. (2004). How do English language learners learn to read? Educational Leadership, 61(6), 52-57.

Stoll, C. (1995). Silicon snake oil. Doubleday, New York.

Şan, M. K., Hira, İ. (2005). Bilgi Toplumu:Bir Risk Olarak Özel Alanın Kayboluşu [Information Society: The disappearance of private sphere as a risk.]. IV. Ulusal Bilgi-Ekonomi and Yönetim Kongresi [IV. National Knowledge Economy and Management Congress], Kocaeli.

TUİK (Turkish Statistical Institute). (2007). Hane Halkı Bilişim Teknolojileri Kullanımı Araştırmas1 [Household Use of Information Technology Survey]. Retrived on 20.03.2014 News Bulletin. http://www.tuik.gov.tr

TUIKK(2011). Hane halkı bilişim teknolojileri kullanım araştırması [Household Use of Information Technology Survey]. http://www.tuik.gov.tr/PreHaberBultenleri.do?id=8572

Turkle, S. (1996). Virtuality and its discontents: searching for community in cyberspace. The American Prospect, 24, pp. 50-57.

Yang, C. K., Choe, B. M., Baity, M., Lee, J. H., \& Cho, J. S. (2005). SCL-90-R and 16PF profiles of senior high school students with excessive internet use. Canadian Journal of Psychiatry, 50,407-414.

Young, K., \& Rodgers, R. (1998). The relationship between depression and internet addiction. CyberPsychology and Behavior, 1,25-28.

Yüksel, S. (2009). Eğitim Fakültesi Öğrencilerinin İnformal Etkileşimleri and Akademik Başarılarıyla İlişsinin İncelenmesi [Informal Interactions of Education Faculty Students and Examination of the Relationship with Their Academic Achievement]. Ahi Evran Üniversitesi Eğitim Fakültesi Dergisi[Journal of Ahi University Faculty of Education], 10(2), 119-127

Zeichner, K.M. \& Tabachnick, B.R. (1985), The Development of Teacher Perspectives: Social Strategies and Institutional Control in The Socialization of Beginning Teachers. Journal of Education of Teaching. Vol. 11, No.1, pp.1-25. 